\title{
Introduction to Special Issue: African Artistic Practices and New Media: Intersections, Volatilities, Futures
}

African artistic practices, new media, new platforms, and their study and use by scholars present opportunities to explore emergent intersections, volatilities, and futures. Questions arising from the intersections between past and present, old and new media, the volatilities of form, and imagined futures in contemporary African cultural production brought scholars from Indiana, Humboldt, and Bayreuth universities together for an interdisciplinary symposium at the Indiana University European Gateway in Berlin, Germany, in June 2017. The symposium was made possible by support of the Indiana University Office of the Vice President for International Affairs; the College of Arts and Humanities Institute; College Associate Deans for Arts and Humanities, Social and Historical Sciences, and International Affairs; The Media School and Department of Cinema and Media Studies; the Institut für Asien- und Afrikawissenschaften, Humboldt-Universität zu Berlin; and the Institut für Afrikastudien, Universität Bayreuth.

Joined by invited artists and other university colleagues, the participants acknowledged many of the challenges facing cultural producers today and discussed approaches to media, new and old. Artists, scholars, and artist-scholars noted the limits and constraints of cultural production on and off the continent today and sought to go beyond the limits of the present. Zimbabwean novelist Petina Gappah, Nigerian satirist Elnathan John, and Nigerian-American artist Emkea Alams deliberated the predicament of trans/national artists and digital space. Gappah read from her novel The Book of Memory, which had been longlisted for the Bailey's Women's Prize for Fiction, shortlisted for the prix Femina étranger, and awarded the McKitterick Prize from the Society of Authors in 2015. ${ }^{1}$ John read from Born on a Tuesday, the Betty Trask Award winner in 2017. Alams discussed his recent video performance art.

The symposium followed a series of similar forums organized by faculty members at Indiana University through New Media and Literary Initiatives in Africa, a project founded in 2012 to consider new Africa-based media and cultural production reaching a global audience. The project involves a multiform resource, providing a platform for media, literary, and artistic endeavors. Scholars associated with it ask critical questions about a range of issues, from new platforms emerging on the African 
continent for dissemination, conversation, and critique, to intellectual and property rights, just access, global piracy of African cultural production, and archiving ephemeral forms of work. Its members seek to collaborate with and participate in rapidly unfolding cultural projects on and off the African continent.

Participants at the symposium traced intersections between past and present, old and new media, to limn the volatilities of form, disciplinary knowledge, and institutions, and to map imagined futures, whether new or old. In asking what constitutes the digital space around African cultural production, Akin Adesokan reminded us that we tend to think of the analog past and the digital future separately, yet rather than viewing them as different, we need to see their simultaneity and what that shift permits us to see as analysts of the cultural. The digital structure of new media has great potential for exploring the present and imagining futures and is perhaps primed to revise calcified notions about the forms of knowledge production. The contributors to this special issue question how academic methods and politics of inquiry and of artistic practices modeled on new media learn from each other.

This situation is more than ripe for serious, wide-ranging, but focused deliberations. The questions that we and our conferees sought to pose, then, considered models for cultural production and models for scholarship of it. Africa is a locus of cultural production, and yet platforms for creating, deliberating, and accessing these creative activities are limited by a host of factors, not the least of which are intellectual property rights, residencies, and funding structures that are largely located in Euro-America, reaching diverse audiences with different sorts of investments and expectations. What research frontiers do scholars as specialists envision in an era of increased integration of different media, communities, and identities? How might different media and/or forms-such as cinema, television, radio, literature, music, photography, art, theater-be productively studied as artistic, historical, and material entities? What is the status of African diasporas-old, new, translocal-in relation to these forms? To what extent are theoretical models favored in the humanities useful in coming to terms with new media and social configurations? What pressure can new media forms put on scholarly frames of inquiry? These and similar questions defined our deliberations and underpin the publications selected from the symposium.

In this, the first of two special issues of Africa Today, each essay explores different slices of the issues mentioned above in a range of different contexts, both geographical and historical, and in different media. The symposium was inaugurated by a keynote address by Jonathan Haynes, the renowned scholar of Nollywood cinema, who had been invited to speak on the topic of Nollywood, the Nigerian cinema phenomenon. In his essay, "Keeping Up: The Corporatization of Nollywood's Economy and Paradigms for Studying African Screen Media," he returns to classic themes in the study of African cultural production, including African cinema and African popular arts, to question the relevance of these paradigms for the 
study of contemporary, globally networked Africa. In Nigeria of late, these frameworks fall short in accounting for recent developments in Nollywood cinema. Of particular note, he considers the transnational corporatization of Nollywood cinema and the shift in media platforms from the sale of discs to internet distribution and television broadcasting, and smartphones and multiplex cinemas that supplement home viewing. Again, rather than viewing old and new media platforms, he reminds us that the two-one unauthorized and the other authorized-run alongside one another.

Lutz Diegner's article, "Good-Bye Book-Welcome, App? Some Observations on the Current Dynamics of Publishing Swahili Novels," examines the potential threat of digital media to conventional publishing in Tanzania through a focus on Uwaridi, a smartphone application for publishing popular novels, run by a collective of writers. In the course of his examination, Diegner takes a critical look at digital publishing and reflects on its implications for the gender gap, the popular-serious literature divide, and Tanzania-Kenya dynamics in the publication of Swahili literature.

Tobias Robert Klein deals with the representation of boarding-school life in different media formats in his article, "Preview for Spirits and Ancestors: Representations of Ghanaian School Life in Audiovisual and Electronic Media." His discussion ranges from school entertainment as an informal training ground for emerging popular musicians to the ways in which different media have singled out and represented varying aspects of boardingschool culture. He gives particular attention to the ways in which school movies and sitcoms have adapted occultism, seniority, and encounters in the classroom to their own generic conventions, and how interactive social media groups adopt features of the school magazine in cultivating nostalgia and school pride.

In "Video Poetry as Re-Creation and Remediation of Oral Performance in the Work of Kgafela oa Magogodi and Chirikure Chirikure," Ricarda de Haas argues that remediated creations are not secondary to live performance but become new art forms in their own right. She demonstrates this in a detailed analysis of the spoken word film i MIKE what i LIKE, produced by Magogodi in collaboration with filmmaker Jiyoti Mistry, and the interactive video installation Directions of Chirikure Chirikure and visual artist Wolfgang Spahn. In her conclusion, she draws out the differences between the artistic genres: intricate "entanglements and flows between live performance and film" occur in i MIKE what i LIKE, but the video installation Directions creates a new performance space, where artists and technologies interact.

Finally, Jane Goodman engages with questions of performance, memory, and technologies of remediation. She takes up Algerian cultural translation in "Embodying Halqa: Algerian Storytelling on a Global Stage." Following the Algerian theater troupe Istijmam's US tour in 2016 as part of the US State Department Center Stage program, she describes the troupe's aim to bring halqa, a form of North African storytelling, to US audiences. In her analysis, new contexts of performance underpin preexisting genres of performance for new outcomes. 
Collectively, these essays bring to light complex dimensions of old and new media and modes of performance and their intertwining in the present. This issue will be followed by a second special issue, which will continue our contributors' discussion of various themes along the lines of entanglements of old and new media, the questions raised by African artists regarding the geographies of production, and the problem of public scholarship, especially for authors with audiences that include persons on the continent. These authors take up the varied topics of film, comics, romance novels, and mediatized images to analyze the politics of cultural production, on and off of the African continent.

Beth Buggenhagen and Maria Grosz-Ngaté, editors

NOTE

1. https://johannesburgreviewofbooks.com/2017/09/04/exclusive-interview-petina-gappah -speaks-about-the-highs-and-lows-of-her-writing-career-and-reveals-details-of-her-next -book. 